\title{
EXPLORATORY FACTOR ANALYSIS (EFA) OF PERFORMANCE OF SMES
}

\author{
Dede Ansyari Guci \\ Universitas Prima Indonesia, Medan, Indonesia. \\ dedeansyariguci@unprimdn.ac.id
}

\begin{abstract}
Performance of SMEs in Indonesia has been a lot of research on previous study. The objective of this research is to develop an idea for calculate performance of SMEs. As many as 100 respondents of pilot test of SME players in Medan, Indonesia. The validation method aimed at validating the parameters which calculate each of the constructs by statitiscally determining that the sample is adequate, using KMO and barlett's test to confirm the effectiveness of the data for multivariate statistical analysis, validating the calculation requirements as applicable to performance of SMEs adept. The result show that the data is valid and reliable design.
\end{abstract}

Keywords: Performance of SMEs, Exploratory Factor Analysis, Small and Medium Enterprises

\section{INTRODUCTION}

Throughout Asia Small and Medium Enterprises are critical component of local economies. Business employing fewer than 20 people employs roughly 90 per cents of the population in Indonesia, a statistic similar to that of other developing countries in Asia [1]. Small and Medium Enterprises are the most dynamic businesses and the most threatened in the global economy.

Indonesia as one of the countries in Asia also feels the benefits derived from the development of small and medium enterprises. According to Minister of Cooperatives and Small, Medium Enterprises (Menkop, dan UKM); Anak Agung Gede Ngurah Prayoga, (2018), small and medium enterprises is one of the supporting economic growths in Indonesia. It must be realized that the presence small and medium enterprises as an integral part of national development could not be ignored. Small and medium enterprises currently represent more than 90 percent of Indonesia's business and accounted for 57 percent of the Gross Domestic Product (GDP) of Indonesia. 
Indonesia's economy will be much stronger if the number of small and medium enterprises in the country could grow even more. Minister for State Owned Enterprises (SOEs) Dahlan Iskan put the current number of small and medium enterprises in Indonesia has reached 3.1\% of the total population [2]. In 2017 the number of small and medium enterprisess in Indonesia is estimated to reach $62,922,617$ businesses. In large numbers and contribute significantly to the national economy, small and medium enterprises considered as a market with huge potential to boost the local economy [3].

\section{LITERATURE REVIEW}

\subsection{Performance of SMEs}

Numerous scholars have been drawn to investigate the performance of Small and Medium Enterprises extensively, as its activity contributes not only to microeconomic outcomes, but also to its performance. Performance improvement is the primary goal of small and medium entreprises, as it demonstrates the level of success of its business operations [4].

According to Machirori (2012), business performance is success measurement index of an Small and Medium Enterprises. There are several variable to measure the performance of small and medium enterprises which determined among others are sales growth of SMEs, a growth of profitability, growth of employee, growth of customer satisfaction [5].

Organizational performance can be explained by different kind of perspectives and there are several aspects which are mutually considered to define organizational performance comprehensively, rather than financial measure of profits which is heavily criticized and profitability reflects the overall performance of profit organizations [6]. Profitability may be expressed in terms of earning per share, return on investment or net income. Employee morale, market share, and social legitimacy (see institutional theory part) may be considered as part of the overall performance in an extremely competitive business world [7]. The concept of organization performance can be express by available question with little acquire using a convenient measures and definitions [8]. 


\subsection{Exploratory Factor Analysis (EFA)}

In order to identify the appropriateness of data for factor analysis, there were three factors that needed to be addressed. The three factors were descriptive statistics, KMO and Barlett's test, and lastly Communalities to know the validity of the instruments of the constructs.

According to Awang, (2015) [9] Kaiser-Meyer-Olkin (KMO) reaches 0.6 and the Barlett's Test must be relevant at $\alpha<0.05$, the correlation matrix factorability is supposed.

However, this study has to take a step into account as the anti-image association for all objects must be above 0.5 , the appropriate amount [10].

According to Tabachnick \& Fidell (2007) [11], there was a communality above 0.3 in the scores offered for all items.

\section{METHODOLOGY}

This research conducted a pilot study of Small and Medium Enterprises (SMEs) in Medan, Indonesia. The data collection instrument of the study was self-administrated surveys where the participants had been asked to complete the question. A number of 100 questionnaires were returned where the questionnaires were distributed and available for exploratory factor analysis (EFA). Analyst has not made a deal on the proportion that becomes troublesome of the lost value part. For Example, Schafer (1999) suggested 5 percent as the limit.

\section{Results and Discussion}

\subsection{Descriptive Statistics}

Below is the result of descriptive statistic for the study. 
Table 1: Descriptive Statistics

\begin{tabular}{lccc}
\hline & Mean & Std. Deviation & Analysis N \\
\hline \hline P1 & 8.43 & .935 & 100 \\
P2 & 8.43 & .946 & 100 \\
P3 & 8.44 & .914 & 100 \\
P4 & 8.16 & .598 & 100 \\
P5 & 8.18 & .730 & 100 \\
\hline
\end{tabular}

The result of the descriptive statistics of performance of SMEs in Table 1 indicates that the mean of $8.16(\mathrm{P} 4)-8.44(\mathrm{P} 3)$ on a scale of $1-10$, which 10 is the highest measure of each item, the scale for each variable of performance of SMEs by respondents tended to be in the middle ranged in value (example above 8 and below 9). The standard deviation for each item ranged from $0.598-0.946$.

\subsection{KMO and Bartlett's Test}

The result of KMO and Bartlett's Test as below

Table 2: KMO and Bartlett's Test

\begin{tabular}{cccc}
\hline \hline $\begin{array}{c}\text { Kaiser-Meyer-Olkin Measure of } \\
\text { Sampling Adequacy. }\end{array}$ & $\begin{array}{c}\text { Bartlett's Test of Approx. Chi- } \\
\text { Square Sphericity. }\end{array}$ & df. & Sig. \\
\hline \hline .796 & 905.324 & 10 & .000 \\
\hline \hline
\end{tabular}

The Kaiser-Meyer-Olkin value in Table 2 was 0.796 , which exceeded the recommended value of 0.60 . This indicates that more than $79 \%$ of the variance in the measured variables is common variance. The Bartlett's Test of Sphericity value from the data set showed statistically significant (Chi-Square with degree of freedom $10=905.324, p=.000$ ). This means that there were strong relationships between the items to investigate. The KaiserMeyer-Olkin and Bartlett's Test of Sphericity value suggest that the data on performance of SMEs in this study was suitable for factor analysis.

\subsection{Communalities}

Below is the result of communalities for the study. 
Table 3: Communalities

\begin{tabular}{lcc}
\hline & Initial & Extraction \\
\hline \hline P1 & 1.000 & .906 \\
P2 & 1.000 & .906 \\
P3 & 1.000 & .922 \\
P4 & 1.000 & .522 \\
P5 & 1.000 & .679 \\
\hline \hline
\end{tabular}

Performance of SMEs communalities result in Table 3 indicates that all the five items in the variable were relatively high, ranging between $0.522(\mathrm{P} 4)$ and $0.922(\mathrm{P} 3)$. This means that the items of the variable fit well with other items of the variable in their factor.

Table 4: Total Variance Explained

\begin{tabular}{|c|c|c|c|c|c|c|}
\hline \multirow[b]{2}{*}{ Components } & \multicolumn{3}{|c|}{$\begin{array}{l}\text { Initial Eigenvalues } \\
\quad \% \text { of }\end{array}$} & \multicolumn{3}{|c|}{$\begin{array}{c}\text { Extraction Sums of Squared Loadings } \\
\% \text { of }\end{array}$} \\
\hline & Total & Variance & Cumulative \% & Total & Variance & Cumulative \% \\
\hline 1 & 3.935 & 78.707 & 78.707 & 3.935 & 78.707 & 78.707 \\
\hline 2 & .796 & 15.927 & 94.635 & & & \\
\hline 3 & .238 & 4.766 & 99.401 & & & \\
\hline 4 & .026 & .510 & 99.912 & & & \\
\hline 5 & .004 & .088 & 100.000 & & & \\
\hline
\end{tabular}

The output result in Table 4 shows that the Exploratory Factor Analysis for performance of SMEs has extracted one dimension for the construct with Eigenvalues exceeding 1.0. The table above shows the output result of the Factor Analysis for performance of SMEs items.

Table 5: Component Matrix ${ }^{\mathrm{a}}$

\begin{tabular}{cc}
\hline \hline Item & Factor loading \\
\hline \hline P1 & .952 \\
P2 & .952 \\
P3 & .960 \\
P4 & .723 \\
P5 & .824 \\
\hline \hline
\end{tabular}

The validity of the instruments of the constructs, performance of SMEs was measured, and the items associated with each construct were examined. The EFA result for performance of SMEs in Table 3.10 indicates that the five items have a factor loading above the recommended value of 0.60 , showing the convergent and discriminant validity of the scales and there are no deleted items, meaning that the construct is suitable for further analysis. 
According to Hair et al. (1997) the factor loading of $+/-0.30$ meet the minimal standard while loading above $+/-0.50$ were practically significant.

\section{CONCLUSION}

The objective of this research is to develop an idea for calculate performance of SMEs in Indonesia. The result of the research findings on the Exploratory Factor Analysis (EFA) shown high calculation such as cronbach's alpha, KMO and Barlett's Test $(>0.60)$ and lastly communalities. It can be conclude that strictly scale acceptance of the present study reliable that the current instrument for performance of SMEs is persistent and well built sample.

\section{REFERENCES}

1. Asia Foundation (2003). Unleashing Small Business Growth, The Asia Foundation Experience in Indonesia.

2. Anak, A.G.N.P., (2018). Usaha Kecil Menengah, Kementerian Koperasi dan Usaha Kecil Menengah. Jakarta.

3. Herdiyan, (2012). Bisnis data center akan tumbuh 100\%, Bisnis Jabar. $21^{\text {st }}$ February 2012.

4. Murphy, G. B., Trailer, J. W., \& Hill, R. C. (1996). Measuring performance in entrepreneurship research. Journal of Business Research, 36: 15-23.

5. Machirori, T.L., (2012). The Impact of Networking on Access to Finance and Performance of SMEs in the Buffalo City Municipality, Eastern Cape, South Africa (Doctoral dissertation, University of Fort Hare).

6. Daft, R.L. (1998). Organization Theory and Design, South-Western College, Publishing, Cincinnati, Ohio.

7. Rauf, A. M. (2007). HRM Sophistication and SME Performance: A Case of Readymade Garment Manufacturers and Exporters in Lahore, Pakistan (Doctoral dissertation, Doctoral thesis, Department of Operations, Organization and Human Resources, Faculty of Management and Governance, University of Twente, Netherlands). 
8. Kirby, J. (2005). "Toward a Theory of High Performance". Harvard Business Review, July-August: $30-39$.

9. Awang, Z.(2015). SEM made simple: a gentle approach to learning structural equation modeling. MPWS Publisher.

10. Byrne, B.M., (2010). Structural Equation modeling with AMOS: Basic concepts, applications and programming, 2nd Edition. Routledge Taylor \& Francis Group.

11. Tabachnick, B.G., \& Fidell, L.S. (2007). Using multivariate statistics (5th ed.). Allyn \& bacon/Pearson Education 